\title{
Delito de maltrato animal en el Anteproyecto de Nuevo Código Penal de Chile de 2018
}

\author{
José Ignacio Binfa Álvarez \\ Abogado Universidad Mayor \\ Diplomado en Criminología Pontificia Universidad Católica \\ Director Fundación Abogados por los Animales \\ Orcid https://orcid.org/0000-0002-2524-6379
}

Recepción: Julio 2020

Aceptación: Octubre 2020

Cita recomendada. BINFA ÁLVAREZ, J.I., Delito de maltrato animal en el Anteproyecto de Nuevo Código Penal de Chile de 2018, dA. Derecho Animal (Forum of Animal Law Studies) 11/3 (2020). - DOI https://doi.org/10.5565/rev/da.512

Agradecimientos. Quiero expresar mi gratitud a Francesca Coghlan y Karin Rosenberg de Fundación Abogados por los Animales quienes revisaron los primeros borradores de este trabajo y con quienes discutí algunas ideas

Resumen

El autor realiza un análisis crítico de la regulación del delito de maltrato animal en el Anteproyecto de Código Penal de Chile del año 2018, a la luz del estado actual de dicho delito tras las reformas introducidas por la Ley $\mathrm{N}^{\circ} 21.020$ en 2017.

Palabras claves: maltrato animal; crueldad animal; Derecho Penal; Derecho Animal; Código Penal chileno; legislación chilena.

Abstract - Animal abuse in the Preliminary Draft of the Criminal Code of Chile in 2018

The author critically reviews the regulation of the crime of animal mistreatment in the Preliminary Draft of the Criminal Code of Chile in 2018, in light of the current status of this crime following the reforms introduced by Law No. 21.020 in 2017.

Keywords: animal mistreatment; animal cruelty; Criminal Law; Animal Law; Chilean Criminal Code; Chilean Law. 


\section{Sumario:}

1. Introducción

2. Acerca del delito de maltrato animal en Chile

3. Delito de maltrato de animal en el Anteproyecto de Código penal

4. Consideraciones del Anteproyecto

5. Propuestas de regulación

6. Conclusiones.

\section{Introducción}

Desde hace unas décadas hasta la actualidad, se ha instalado en Chile la necesidad de modernizar nuestro sistema de justicia penal, tarea que sólo se ha realizado de forma parcial. En el ámbito procesal penal, esto se ha concretado con la publicación del -entonces- nuevo Código Procesal Penal el 12 de octubre del año 2000, que marcaría el inicio de la Reforma Procesal Penal a lo largo del país. Paralelo a esto, en los diversos gobiernos del siglo XXI, se organizarían sendas Comisiones para formular un nuevo código penal que buscara actualizar y subsanar los defectos del Código Penal de 1874, vigente a la fecha. Este trabajo prelegislativo se iniciaría con la Comisión de Estudio Para la Elaboración de un Anteproyecto de Código Penal o "Comisión Foro Penal" del Ministerio de Justicia durante el gobierno del Presidente de la República Don Ricardo Lagos Escobar (2000-2006), la cual culminaría su trabajo presentando el Anteproyecto de Código Penal del año $2005^{1}$. Este Anteproyecto no vería la luz, pues con posterioridad se formarían nuevas Comisiones convocadas por distintos gobiernos en los años $2013^{2}, 2015^{3}$ y $2017^{4}$, cada una con su propio Anteproyecto.

La última Comisión a cargo de la materia fue convocada durante el segundo mandato del Presidente de la República Don Sebastián Piñera Echeñique y fue integrada por importantes juristas nacionales ${ }^{5}$ quienes el día 17 de octubre de 2018 presentarían al Ministerio de Justicia y Derechos Humanos el Anteproyecto de Código Penal del año $2018^{6}$ y, de acuerdo a su carta de entrega: "El texto es el resultado de un intenso trabajo de aprovechamiento y, a nuestro entender, mejoramiento de los anteproyectos que fueron preparados durante los años 2013 y 2015 por comisiones nombradas al efecto por el mismo Ministerio y de las que, junto a los comisionados Luis Ortiz Quiroga y Juan Pablo Mañalich Raffo, los suscritos formamos parte en distintas condiciones." 7

El APCP aún no ha sido ingresado para su discusión en el Congreso Nacional, encontrándose en etapa prelegislativa, en la cual ya se le han formulado observaciones y propuestas por parte de los cuerpos académicos de diversas Facultades de Derecho del país ${ }^{8}$.

Paralelo a esto, el delito de maltrato animal ha vivido su propia serie de reformas, principalmente en los últimos treinta años. Desde sus orígenes como falta penal en el texto original del Código Penal chileno, pasando por su elevación a la categoría de delito con la Ley $\mathrm{N}^{\circ} 18.859$ de 1989 y luego con los intentos de

\footnotetext{
${ }^{1}$ Anteproyecto de Nuevo Código Penal (2005). En línea en:

http://www.icpenales.cl/website/www.icpenales.cl/uploads/pdf/anteproyecto-foro-penal.pdf [último acceso el 21 de septiembre de 2020].

${ }^{2}$ Ministerio de Justicia y Derechos Humanos, Anteproyecto para Nuevo Código Penal de 2013. En línea en:

https://www.minjusticia.gob.cl/anteproyecto-para-nuevo-codigo-penal/anteproyecto-codigo-penal-2013/ [último acceso el 21 de septiembre de 2020].

${ }^{3}$ Ministerio de Justicia y Derechos Humanos, Anteproyecto para Nuevo Código Penal de 2015. En línea en:

https://www.minjusticia.gob.cl/anteproyecto-para-nuevo-codigo-penal/anteproyecto-codigo-penal-2015/ [último acceso el 21 de septiembre de 2020].

${ }^{4}$ Ministerio de Justicia y Derechos Humanos, Anteproyecto para Nuevo Código Penal de 2018. En línea en:

https://www.minjusticia.gob.cl/anteproyecto-para-nuevo-codigo-penal/ [último acceso el 21 de septiembre de 2020].

${ }^{5}$ Los académicos que componen esta Comisión son Juan Domingo Acosta Sánchez, Antonio Bascuñán Rodríguez, Jorge Bofill Genzsch, Jaime Couso Salas, Juan Pablo Cox Leixelard, Héctor Hernández Basualto, Francisco Maldonado Fuentes, Alex van Weezel De la Cruz y Javier Wilenmann von Bernath.

${ }^{6}$ En adelante APCP.

${ }^{7}$ Carta de Entrega de Anteproyecto de Código Penal dirigida al Ministro de Justicia y Derechos Humanos, Don Hernán Larraín Fernández, de fecha 17 de octubre de 2018. En línea en: https://www.minjusticia.gob.cl/media/2018/10/Carta-entrega-Anteproyectode-C\%C3\%B3digo-Penal-2018.pdf [último acceso el 21 de septiembre de 2020].

${ }^{8}$ Ministerio de Justicia y Derechos Humanos, Anteproyecto para Nuevo Código Penal de 2018. En línea en:

https://www.minjusticia.gob.cl/anteproyecto-para-nuevo-codigo-penal/ [último acceso el 21 de septiembre de 2020].
} 
dotar de este delito de mayor eficacia a través de las reformas introducidas durante el siglo XXI, por la Ley $\mathrm{N}^{\circ} 20.380$ en 2009 y la Ley $\mathrm{N}^{\circ} 21.020$ en 2017, este ilícito ha ido despertando cada vez más interés en la dogmática como también en la práctica judicial ${ }^{9}$.

Dicho todo lo anterior, cabe hacernos las siguientes preguntas: ¿De qué forma el APCP regulará esta materia? ¿Seguirá el mismo derrotero del legislador de los últimos treinta años? De no ser así ¿Será la alternativa propuesta por el APCP la más idónea para otorgar protección al animal no humano? En las siguientes líneas, se tratará de responder estas preguntas. En primer lugar, se analizará la evolución del delito de maltrato animal en Chile, repasando brevemente en la actual regulación de este delito, para, a continuación, exponer la regulación propuesta por el APCP respecto de dicho delito, ofreciendo algunas críticas al respecto.

\section{Acerca del delito de maltrato animal en Chile 2.1 Reseña histórica del maltrato animal en Chile 2.1.1 Maltrato animal como falta}

El delito de maltrato animal en Chile es fruto de una evolución que tiene sus orígenes en el texto original del Código Penal actualmente vigente. En un principio, se establecía una falta relacionada al maltrato contra animales en su artículo $496 \mathrm{~N}^{\circ} 35^{10}$ que señalaba:

"Sufrirán la pena de prisión en su grado mínimo conmutable en multa de uno a treinta pesos:
El que se hiciere culpable de actos de crueldad o mal trato excesivo para con los animales."

El bien jurídico de esta falta, tal como se ha sostenido en la doctrina ${ }^{11}$, estaría relacionado a la moral y buenas costumbres, de acuerdo con aquella concepción filosófica que consideraría los malos tratos hacia los animales como un acto contrario a la ética y un indicio o predictor de futuras agresiones a otros humanos ${ }^{12}$, esto último, es respaldado por estudios criminológicos realizados a lo largo del siglo $\mathrm{XX}^{13}$. En atención a su configuración típica ${ }^{14} \mathrm{y}$ calidad de falta, esta figura no sería objeto de atención por parte de la doctrina y la jurisprudencia ${ }^{15}$, por lo que la protección penal del animal no humano, en cuanto cosa para nuestro ordenamiento jurídico, sería más fuerte desde las normas de protección a la propiedad ${ }^{16}$.

\subsubsection{Maltrato animal como delito}

El maltrato animal se mantendría como falta durante el siglo XIX y gran parte del siglo XX, existiendo varios intentos de elevar estos actos a la categoría de delito ${ }^{17}$, pero no sería hasta el año 1989 que esto se lograría a través de la Ley $\mathrm{N}^{\circ} 18.859$ que Modifica el Código Penal, en lo relativo a la protección animal, publicada durante los últimos años de la dictadura cívico-militar de Chile. Esta ley, en su artículo único, derogaría la falta del artículo $496 \mathrm{~N}^{\circ} 35$ del Código Penal e incorporaría el nuevo artículo 291 bis que regularía el maltrato animal de la siguiente forma:

\footnotetext{
${ }^{9}$ De acuerdo con las estadísticas de la Policía de Investigaciones de Chile, en los últimos años las denuncias por este delito han sufrido un aumento significativo. Así, entre 2017 y 2018 se registró un alza en un 31\% de denuncias de casos de maltrato animal (de 1610 a 2111), lo cual es coincidente con la publicación de la Ley $\mathrm{N}^{\circ} 21.020$ que, como se verá más adelante, introdujo importantes reformas a este delito. Policía de Investigaciones - Aumentan investigaciones por maltrato animal. En línea: https:/www.pdichile.cl/centro-deprensa/detalle-prensa/2019/02/15/aumentan-investigaciones-por-maltrato-animal [último acceso el 21 de septiembre de 2020].

${ }^{10}$ Versión original de este artículo en Biblioteca del Congreso Nacional. En línea en:

https://www.leychile.cl/Navegar?idNorma=1984\&idParte=9672794\&idVersion=1875-03-01 [último acceso el 21 de septiembre de 2020].

${ }^{11}$ Por todos, GUZMAN DÁLBORA, J., El delito de maltrato de animales, en Estudios Penales (Santiago 2009) 272.

${ }^{12}$ Cfr. GUZMAN DÁLBORA, J., op. cit., pp. 250-252; DE LAS HERAS CRUZ, J., El bienestar animal como bien jurídico-penal, en CHIBLE VILLADANGOS, M. y GALLEGO SAADE J. (eds.): Derecho animal teoría y práctica (Santiago 2018) 197-198; TAPIA THENOUX, M. F. El estatus jurídico y moral del animal no-humano (Santiago 2020) 71-73.

${ }^{13}$ Sobre esto, la National Link Coalition se ha encargado de recopilar estudios sobre el vínculo entre maltrato animal y violencia contra los humanos. Más información en: https://nationallinkcoalition.org/ [último acceso el 21 de septiembre de 2020].

${ }^{14}$ Una de las dificultades de esta falta eran sus problemas interpretativos en torno al verbo rector "actos de crueldad y maltrato" o las voces "excesivo" y "culpable", pero que no encontraron respuestas. En este sentido, MELLA PÉREZ, R. A, Evolución jurisprudencial del delito de maltrato o crueldad animal en Chile, en dA. Derecho Animal (Forum of Animal Law Studies) 9/3 (2018) 151.

${ }^{15}$ GUZMAN DÁLBORA, J., op. cit., p. 272.

${ }^{16}$ LEIVA ILABACA, C., El delito de maltrato animal en Chile: Historia del artículo 291 bis y análisis crítico a la luz del nuevo tipo penal incorporado por la Ley $\mathrm{N}^{\circ}$ 21.020, en CHIBLE VILLADANGOS, M. y GALLEGO SAADE J. (eds.): Derecho animal teoría y práctica (Santiago 2018) 406.

${ }^{17}$ Así, diversos proyectos de este tipo se presentarían durante la segunda mitad del siglo XX, ninguno de ellos distinguiendo clases de maltrato animal ni cual sería el animal no humano objeto de protección. Vid., LEIVA ILABACA, C., op. cit., p. 407.

136 Derecho Animal. Forum of Animal Law Studies, vol. 11/3
} 
"El que cometiere actos de maltrato o crueldad con animales, será castigado con la pena de presidio menor en su grado mínimo y multa de uno a diez ingresos mínimos mensuales o solo a esta última."

Esta norma se insertaría en el párrafo IX "De los delitos relativos a la salud animal y vegetal", en el Título Sexto "De los crímenes y simples delitos contra el orden y la seguridad públicos cometidos por particulares" del Libro Segundo del Código Penal y, de acuerdo a la escasa información disponible de su discusión en la Junta Nacional de Gobierno, tendría como motivación castigar actos de crueldad contra los animales para evitar la violencia contra los humanos siendo, finalmente, el interés protegido en este tipo penal la comunidad ${ }^{18}$, es decir, se seguiría la orientación política-criminal contenida en la falta ya comentada, considerando el bien jurídico de este delito como uno de carácter colectivo, que resguardaría intereses humanos en lugar de los del animal no humano. Debido a la baja punibilidad y los problemas interpretativos que trajo la deficiente técnica legislativa que utilizó la fórmula-ambigua de "actos de maltrato y crueldad" que delegaba al juez la delimitación de este tipo penal ${ }^{19}$, este delito seguiría siendo poco aplicable ${ }^{20}$.

El tipo penal del 291 bis se mantendría inalterado hasta el año 2009, tras la publicación de la Ley $\mathrm{N}^{\circ}$ 20.380 sobre "Protección de los animales", que en su artículo 18 reformaría este delito para aumentar levemente su pena, quedando su nueva redacción de la siguiente forma:

"El que cometiere actos de maltrato o crueldad con animales, será castigado con la pena de presidio menor en sus grados mínimo a medio y multa de dos a treinta unidades tributarias mensuales o solo a esta última."

Sin perjuicio de esta leve reforma, que mantuvo los problemas ya señalados, tras la Ley $\mathrm{N}^{\circ} 20.380$ es posible señalar que la consideración del animal no humano en nuestra legislación ha variado. Así, de su estatus jurídico de cosa (bienes muebles semovientes de acuerdo al artículo 567 del Código Civil), mutarían a ser objetos de protección legal, esto en atención a que, de la lectura de los artículos $1^{\circ 21}, 2^{\circ 22}$ y $3^{\circ 23}$ de esta ley se puede identificar por primera vez en nuestra legislación la consideración de los animales como seres dotados de sensibilidad ${ }^{24}$, consagrando el interés de no padecer sufrimientos y reconociendo la importancia de protegerlos y darle respeto, a través de la educación principalmente y también imponiendo deberes de cuidados básicos a los responsables de los animales no humanos. Desde este momento, es claro el viraje de nuestra legislación en orden a considerar como bien jurídico de este delito al bienestar animal, al menos en cuanto bien jurídico colectivo del cual la comunidad sería titular.

\subsection{Regulación actual}

Sin embargo, no sería hasta la publicación de Ley Nº 21.020 sobre Tenencia Responsable de Mascotas y Animales de Compañía que se incluiría una regulación más robusta de este delito, tratando de resolver los problemas de su redacción original. Así, el artículo 36 de dicha ley reformó este delito modificando el artículo 291 bis e introduciendo un nuevo artículo 291 ter al Código Penal, por lo que este delito quedó redactado de la siguiente forma:

\section{"Artículo 291 bis.}

\footnotetext{
${ }^{18}$ Ibid., pp. 408-409.

${ }^{19}$ WILENMANN VON BERNATH, J., Causación lícita de lesiones o de la muerte de animales en el sistema jurídico chileno tras la Ley $\mathrm{N}^{\circ}$ 21.020, en CHIBLE VILLADANGOS, M. y GALLEGO SAADE J. (eds.): Derecho animal teoría y práctica (Santiago 2018) 436-439.

${ }^{20}$ LEIVA ILABACA, C., op. cit., pp. 408-409.

21 “Artículo $1^{\circ}$. - Esta ley establece normas destinadas a conocer, proteger y respetar a los animales, como seres vivos y parte de la naturaleza, con el fin de darles un trato adecuado y evitarles sufrimientos innecesarios.

El reglamento definirá las distintas categorías de animales domésticos y silvestres, según especie.”

${ }^{22}$ “Artículo $2^{\circ}$. - El proceso educativo, en sus niveles básico y medio, deberá inculcar el sentido de respeto y protección a los animales, como seres vivientes y sensibles que forman parte de la naturaleza.

La autoridad dará prioridad a la educación para la tenencia responsable de animales, a fin de controlar especialmente la población canina y felina, procurando, además, que para este efecto se apliquen otras medidas integrales de prevención, como el control sistemático de fertilidad canina y felina y de factores ambientales relacionados, y el registro e identificación de estos animales domésticos."

${ }^{23}$ “Artículo $3^{\circ}$. - Toda persona que, a cualquier título, tenga un animal, debe cuidarlo y proporcionarle alimento y albergue adecuados, de acuerdo, al menos, a las necesidades mínimas de cada especie y categoría y a los antecedentes aportados por la ciencia y la experiencia.

La libertad de movimiento de los animales silvestres no debe ser restringida de manera innecesaria, especialmente si ello les ocasionare sufrimiento y alteración de su normal desarrollo."
}

${ }^{24}$ Cfr. MONTES FRANCESCHINI, M., Derecho animal en Chile (Santiago 2018) 54. 
El que cometiere actos de maltrato o crueldad con animales será castigado con la pena de presidio menor en sus grados mínimo a medio y multa de dos a treinta unidades tributarias mensuales, o solo con esta última.

Si como resultado de una acción u omisión se causare al animal daño, la pena será presidio menor en sus grados mínimo a medio y multa de diez a treinta unidades tributarias mensuales, además de la accesoria de inhabilidad absoluta perpetua para la tenencia de cualquier tipo de animales.

Si como resultado de las referidas acción u omisión se causaren lesiones que menoscaben gravemente la integridad fisica o provocaren la muerte del animal se impondrá la pena de presidio menor en su grado medio y multa de veinte a treinta unidades tributarias mensuales, además de la accesoria de inhabilidad absoluta perpetua para la tenencia de animales.

Artículo 291 ter.

Para los efectos del artículo anterior se entenderá por acto de maltrato o crueldad con animales toda acción u omisión, ocasional o reiterada, que injustificadamente causare daño, dolor o sufrimiento al animal."

Las modificaciones introducidas se pueden resumir en los siguientes aspectos: definir actos de maltrato y crueldad contra animales, graduar la pena de acuerdo con la causación de determinados resultados y establecer una nueva pena accesoria consistente en la inhabilidad absoluta perpetua para la tenencia de animales para los casos de mayor gravedad.

Por otro lado, la discusión del bien jurídico ha seguido evolucionando, pues la definición del artículo 291 ter del Código Penal permite entender al individuo animal no humano como el afectado por el delito, matizando más la forma en que el Derecho penal lo protege. En este sentido, se discutiría si el bien jurídico protegido por esta norma sería el bienestar animal como bien colectivo ${ }^{25}$, o si se trataría del bienestar animal y salud ${ }^{26}$ del individuo animal no humano afectado como bien jurídico personalísimo ${ }^{27}$. En cualquier caso, que el bien jurídico no se refiera a objetos distintos al patrimonio del dueño del animal no humano, es del todo relevante pues tiene como consecuencia la inadmisibilidad de acuerdos reparatorios como forma de término en las causas de maltrato animal ${ }^{28}$.

\subsubsection{Tipo objetivo}

Si bien la redacción del artículo 291 bis del Código Penal se ha visto inalterada, manteniendo como verbo rector de este delito "cometer actos de maltrato o crueldad con animales", esto actualmente está definido en el artículo 291 ter del Código Penal como "toda acción u omisión, ocasional o reiterada, que injustificadamente causare daño, dolor o sufrimiento al animal", por lo que podemos entender que la conducta es la causación de ciertos resultados típicos al animal. De esta forma, el delito se puede cometer tanto por acción, como por omisión, a través de cualquier medio o mecanismo, material o inmaterial, que permita la causación de daño, dolor o sufrimiento.

El objeto material, esto es, la cosa o individuo sobre la cual recae el delito, sería el cuerpo del animal no humano ${ }^{29}$. En cuanto a qué animal o animales se tratan, si bien el tipo penal no distingue especie alguna, a diferencia de legislaciones como la española ${ }^{30}$, la doctrina ha buscado delimitar este objeto. Así, se ha sostenido que habría que interpretar "animal" en un sentido natural como "ser orgánico que vive, siente y se mueve por su propio impulso" 31 ; por otro lado, también se ha sostenido que se trataría de, al menos, todos los animales vertebrados pues cuentan con capacidad de experimentar dolor ${ }^{32}$. En ambos casos se tendría presente

\footnotetext{
${ }^{25}$ Cfr. VON MUHLENBROCK CANTALLOPTS, M., Rodeo y maltrato animal, en MATUS ACUÑA, J. P., (dir.): Derecho penal del medio ambiente chileno (Valencia 2019) 218-221, quien, si bien reconoce que el artículo 291 bis "resguarda la salud de un espécimen animal no humano en particular", termina concluyendo que el bien jurídico de este delito es el "bienestar de los animales no humanos", siendo este un bien jurídico colectivo para esta autora.

${ }^{26}$ TAPIA THENOUX, M. F. op. cit., p. 77.

${ }^{27}$ MAÑALICH, J. P., Animalidad y Subjetividad. Los animales (no humanos) como sujetos-de-derecho, en Revista de Derecho (Valdivia), 31/2 (2018) 324.

${ }^{28} \mathrm{El}$ artículo 241 del Código Procesal Penal señala respecto de la procedencia del acuerdo reparatorio, que este puede sólo versar sobre "hechos investigados que afectaren bienes jurídicos disponibles de carácter patrimonial, consistieren en lesiones menos graves o constituyeren delitos culposos", por lo que claramente el bienestar animal, ya sea considerado como bien jurídico colectivo o como bien jurídico individualísimo del animal no humano, queda fuera de esta norma.

${ }^{29}$ Por todos LEIVA ILABACA, C., op. cit., p. 418.

${ }^{30}$ El Código Penal español contempla el delito de maltrato animal en su artículo 337.1 delimitando el objeto material a: “a) un animal doméstico o amansado, b) un animal de los que habitualmente están domesticados, c) un animal que temporal o permanentemente vive bajo control humano, o d) cualquier animal que no viva en estado salvaje."

${ }^{31}$ VON MUHLENBROCK CANTALLOPTS, M., op. cit., p. 225.

${ }^{32}$ Cf. LEIVA ILABACA, C., op. cit., p 418; y TAPIA THENOUX, M. F., op. cit., p. 80. De otra opinión MeLLA, quien problematiza 138 Derecho Animal. Forum of Animal Law Studies, vol. 11/3
} 
que la actual regulación protege al animal no humano en cuanto individuo.

En cuanto al sujeto activo, al ser un delito común, puede ser cualquier persona independiente de su relación con el animal no humano afectado. Así, tratándose de animales de compañía, por ejemplo, podrá ser tanto el tenedor "responsable" 33 o un tercero desconocido. Ahora bien, esta situación cambia cuando se trata de hechos constitutivos de delito de maltrato animal por omisión, en cuyo caso estamos en presencia de un delito especial propio de quien omite un deber de cuidado respecto del animal en cuestión ${ }^{34}$. Así, se requerirá de una posición de garante, las cuales pueden provenir de la ley ${ }^{35}$, el contrato o el actuar precedente ${ }^{36}$.

Por otro lado, en cuanto al sujeto pasivo, es decir, el ofendido y titular del bien jurídico de este delito, podemos encontrar dos posturas en la doctrina nacional: quienes consideran que este bien jurídico es personalísimo, ven como el ofendido de este delito al animal no humano y no su dueño, poseedor o la sociedad en su conjunto ${ }^{37}$. En contra de esta postura, se ha afirmado que, dado que el animal no humano mantiene el estatus jurídico de bien mueble como se explicó, es difícil atribuirle la calidad de sujeto pasivo de este delito ${ }^{38}$, sumado a que no son considerados como víctimas de delito de conformidad al artículo 108 del Código Procesal Penal $^{39}$, siendo la comunidad en su conjunto la ofendida ${ }^{40}$. En mi opinión, creo que la primera postura es la correcta pues, si bien es cierto que nuestra legislación continúa cosificando al animal no humano al mantenerlos en el estatus de las cosas, no podemos negar que en los últimos años la consideración de ellos ha ido variando de forma importante, limitándose cada vez más la manera en que el humano puede disponer del animal no humano. Así, nuestra legislación actualmente reconoce ciertos intereses del animal no humano, siendo claro el reconocimiento del interés de no sufrir, el cual se ve afectado cuando el bienestar y salud del individuo animal se lesiona con actos de maltrato animal.

En cuanto al resultado, quedó atrás la discusión respecto de si este delito es de mera actividad o de resultado ${ }^{41}$. Hoy queda claro que se exige un resultado de daño, dolor o sufrimiento al animal. Sobre el alcance de estos conceptos, a la fecha la doctrina nacional no ha delimitado el alcance de estos términos, sin perjuicio que podemos entender daño como un menoscabo o detrimento, el cual va dirigido contra el bienestar y salud del animal no humano; en cuanto a los conceptos dolor y sufrimiento, estos suelen considerarse sinónimos y así lo podemos desprender de la RAE al definir dolor como "sensación molesta y aflictiva de una parte del

que sólo los vertebrados sean capaces de sentir dolor, pues existirían estudios que afirmarían que ciertos invertebrados también poseerían dicha capacidad, sin perjuicio que reconoce en la teoría de la adecuación social o en la noción de riesgo permitido formas de delimitar este asunto, vid., MELLA PÉREZ, R. A, op. cit., pp. 157-158.

${ }^{33}$ El Reglamento Decreto 1007 del Ministerio del Interior y Seguridad Pública en su artículo 1 letra x define tenedor responsable de mascota o animal de compañía de la siguiente forma: "El dueño o poseedor de una mascota o animal de compañía, o aquella persona natural o jurídica que asume la tenencia responsable de un animal que reiteradamente alimenta, alberga y utiliza para fines de compañía, trabajo, vigilancia u otros."

${ }^{34}$ Por todos LEIVA ILABACA, C., op. cit., p 417.

${ }^{35}$ Ya en la Ley $\mathrm{N}^{\circ} 20.380$ es posible hallar una fuente legal de posición de garante de protección en el inciso primero del artículo $3^{\circ}$, que señala: "Toda persona que, a cualquier título, tenga un animal, debe cuidarlo y proporcionarle alimento y albergue adecuados, de acuerdo, al menos, a las necesidades mínimas de cada especie y categoría y a los antecedentes aportados por la ciencia y la experiencia." A su vez, también es posible identificar en la Ley $\mathrm{N}^{\circ} 21.020$ el establecimiento de una posición de garante de vigilancia para el dueño o poseedor de animales de compañía, al considerarlos como una verdadera fuente de peligro en el artículo 10, que señala: "Será responsable de las mascotas o animales de compañía su dueño o poseedor. Sin perjuicio de lo anterior, quien tenga un animal bajo su cuidado responderá como fiador de los daños producidos por éste, en los términos establecidos en el Título XXXVI del Libro Cuarto del Código Civil."

${ }^{36}$ CURY URZUA, E., Derecho penal parte general (Santiago 2010) 681-683.

${ }^{37}$ Cfr. TAPIA THENOUX, M. F. op. cit., p. 81 , quien advierte que tradicionalmente ha sido difícil reconocer la condición de titular de derechos al animal no humano, pero que tras las modificaciones de la Ley $\mathrm{N}^{\circ} 21.020$ a este delito, se considera individualmente al animal afectado; también MELLA PÉREZ, R. A, op. cit., p. 160, quien afirma que, de este modo, habría coincidencia entre sujeto pasivo y objeto material de este delito.

${ }^{38}$ LEIVA ILABACA, C., op. cit., p. 418, quien, sin perjuicio de esto, advierte que tímidamente se ha ido reconociendo una relación directa entre bien jurídico y sujeto pasivo, lo que daría paso a un planteamiento no pacífico tendiente a descartar que el sujeto pasivo sean las personas o sus sensibilidades ante los actos de maltrato, proponiendo en su lugar al animal no humano como sujeto pasivo y víctima del delito.

39“'Artículo 108.- Concepto. Para los efectos de este Código, se considera víctima al ofendido por el delito.

En los delitos cuya consecuencia fuere la muerte del ofendido y en los casos en que éste no pudiere ejercer los derechos que en este Código se le otorgan, se considerará víctima:

a) al cónyuge o al conviviente civil y a los hijos;

b) a los ascendientes;

c) al conviviente;

d) a los hermanos, y

e) al adoptado o adoptante.

Para los efectos de su intervención en el procedimiento, la enumeración precedente constituye un orden de prelación, de manera que la intervención de una o más personas pertenecientes a una categoría excluye a las comprendidas en las categorías siguientes.” ${ }^{40}$ En este sentido, VON MUHLENBROCK CANTALLOPTS, M., op. cit., p. 222.

${ }^{41}$ Sobre esto ya se pronunciaba GUZMÁN DALBORA previo a la reforma comentada. Vid., GUZMAN DÁLBORA, J., op. cit., pp. $278-$ 279. 
cuerpo por causa interior o exterior" y sufrimiento "padecimiento, dolor, pena", como también en la escasa jurisprudencia reciente ${ }^{42}$, sin perjuicio que los podemos interpretar como afectaciones a la integridad física o psíquica del animal no humano.

Relacionado a esto podemos identificar que el delito en su artículo 291 bis tiene una figura base en el inciso primero, y dos formas calificadas en los incisos segundo y tercero. Mientras la figura base se relaciona con la causación de dolor o sufrimiento, la figura calificada del inciso segundo exige como resultado daño. En cuanto a la figura calificada del inciso tercero, esta posee una mayor descripción al exigir la causación "lesiones que menoscaben gravemente la integridad fisica o "provocaren la muerte". En cuanto a la gravedad de las lesiones, se ha sostenido que deben establecerse caso a caso, "teniendo en consideración el grado de desarrollo del animal, su edad, estado de salud y su capacidad para sentir dolor"43. Así, tanto las lesiones que menoscaban gravemente la integridad física como la muerte (entendida como cesación de la vida del animal), se consideran como formas especial de daño para efectos de agravar la pena.

\subsubsection{Tipo subjetivo}

No existen exigencias de elementos subjetivos especiales en este tipo penal, por lo que es posible aplicar las reglas generales. Así, respecto de este delito es admisible tanto su comisión con dolo directo como con dolo eventual.

Respecto de la culpa, cabe mencionar que, por regla general, el artículo $10 \mathrm{~N}^{\circ} 13$ del Código Penal exime de responsabilidad penal a quien comete un delito culposo. Las excepciones a esto las encontramos en los artículos 490 a 493 del Código Penal, que disponen que se castigarán los delitos culposos sólo tratándose de delitos contra las personas o cuando así lo disponga un tipo penal expresamente. De este modo, no encontrándose expresamente castigado el maltrato animal a título de culpa, hechos como, por ejemplo, las negligencias médico-veterinarias serían subjetivamente atípicas.

\subsubsection{Antijuridicidad}

La nueva regulación introdujo la voz "injustificadamente", la cual también está presente en el delito de maltrato animal del artículo 337.1 del Código Penal español, respecto de la cual se ha dicho que serviría para dejar a salvo festividades tradicionales como las corridas de toro ante las justificaciones administrativas existentes $^{44}$. Entre nosotros, se entiende como una remisión a las causales de justificación generales contempladas en el ordenamiento jurídico, como también a situaciones de justificabilidad que el ejercicio doctrinario y jurisprudencial pueda ir creando. Debido a lo anterior, de acuerdo con WILENMANN, es posible establecer un sistema de tres niveles de justificabilidad ${ }^{45}$ :

- Aplicabilidad de una causa de justificación especialmente referida al trato con animales: se debe atender a la regulación sectorial, la cual puede ser tanto ganadera, sobre caza, pesca, investigación con seres vivos y prácticas recreativas que utilicen animales. Así, existe una variedad de leyes que permiten legitimar actividades que naturalmente podríamos considerar explotación, pero socialmente están tolerado. Esto se hace evidente en el caso de la Ley N 19.162 o "Ley de Carnes", la Ley $\mathrm{N}^{\circ} 19.473$ sobre Caza y la Ley N 18.892 sobre Pesca, pero también está presente en la Ley $\mathrm{N}^{\circ} 20.380$ que, a propósito de la protección animal, regula circos y zoológicos (artículo 5), experimentación con animales (título IV), así como también menciona que los deportes en que "participen" animales se rigen por sus propios reglamentos (artículo. 16) y también en la Ley $\mathrm{N}^{\circ}$ 21.020 al regular la venta y cría de animales de compañía (título VIII), entre otras actividades que tengan regulaciones especiales. Además de estas actividades e industrias, existen casos en que se permitiría la muerte de un animal por razones sanitarias, como por ejemplo el Reglamento Decreto 1 del Ministerio de Salud sobre Prevención y Control de Rabia que autoriza la "erradicación” de colonias de murciélagos que representen un riesgo de contagio o difusión de rabia (artículo 8), también la eutanasia de animales mordedores con síntomas asociables a rabia (artículo 16) y la eutanasia de aquellos animales sin vacuna antirrábica vigente que fueron expuestos a animales

\footnotetext{
${ }^{42} \mathrm{La}$ jurisprudencia sobre delito de maltrato animal es escasa y poco prolija a la hora de interpretar este tipo penal. Sobre el uso de dolor y sufrimiento como sinónimos, vid.; Sentencia Segundo Tribunal Oral en lo Penal de Santiago 26/2/2020 RIT 314-2019; Sentencia Séptimo Tribunal Oral en lo Penal de Santiago 21/12/2019 RIT 277-2019; Sentencia Tribunal Oral en lo Penal de Valparaíso 12/10/2018 RIT 490-2017; Sentencia Tribunal Oral en lo Penal de San Antonio 13/8/2018 RIT 207-2017.

${ }^{43}$ TAPIA THENOUX, M. F. op. cit., p. 81.

${ }^{44}$ MESÍAS RODRÍGUEZ, J., Los delitos de maltrato y abandono de animales en el Código Penal español, en dA. Derecho Animal (Forum of Animal Law Studies) 9/2 (2018) 82.

${ }^{45}$ Este sistema es propuesto en WILENMANN VON BERNATH, J., op. cit., pp. 446-450.

140 Derecho Animal. Forum of Animal Law Studies, vol. 11/3
} 
rabiosos o con sintomatología de rabia (artículo 21); por otro lado, el Código Sanitario, en su artículo 31, también autoriza la muerte de animales en caso que estos sean propagadores de enfermedades en el contexto de peligro de epidemias o cuando estas hubieren sido declarada. En todos estos casos, el derecho autorizaría la realización de dichas actividades y causaciones de muerte, por lo que no es necesario de hablar de una causal de justificación expresa para ellas. Ahora bien, toda conducta que no se ajuste a la regulación sectorial y cause daño, dolor o sufrimiento a un animal no humano, podrá ser considerada como delito de maltrato animal ${ }^{46}$.

- Aplicabilidad de una causa de justificación general: aquí rigen las reglas generales de justificación del artículo 10 del Código Penal, por lo que entran en juego la legitima defensa ( $\mathrm{N}^{\circ} 4,5$ y 6 ), el estado de necesidad $\left(\mathrm{N}^{\circ} 7\right)$, obrar en cumplimiento de un deber o ejercicio legítimo de un derecho, autoridad, oficio o cargo ( $\left.\mathrm{N}^{\circ} 10\right)$ o la omisión por causa legítima $\left(\mathrm{N}^{\circ} 12\right)$.

- Juicio general de justificabilidad: fuera de los casos anteriores, se plantea el problema sobre cuales serían los casos de maltrato animal justificados sin referencia a otras normas jurídicas. La regulación de este delito no nos orienta sobre cómo proceder, por lo que WILENMANN propone un razonamiento basado en dos pasos: evaluar el fin perseguido por la causación del resultado de daño, dolor o sufrimiento, el cual debe ser adecuado, y luego establecer que dicho fin tuvo lugar a través de un medio adecuado. A este respecto, se ha sostenido que causaciones lícitas del resultado serían los procedimientos quirúrgicos, procedimientos investigativos no invasivos ${ }^{47} \mathrm{y}$ en general todos los menoscabos que provean un beneficio a corto o largo plazo o permitan disminuir otros sufrimientos al animal no humano, dentro de lo cual encontraríamos a la eutanasia ${ }^{48}$.

\subsubsection{Penalidad}

Ya se explico que existen tres figuras en el delito de maltrato animal, dependiendo del resultado que se produce. Tras las reformas, entre estas figuras existe una suerte de cuantificación de la pena. Así, en la figura base del inciso primero, se mantiene la alternatividad de la pena entre el presidio menor en grados mínimo a medio (esto es, de 61 días a 3 años de pena privativa de libertad) y/o multa de dos a treinta unidades tributarias mensuales.

Por otro lado, la figura agravada del inciso segundo mantiene la extensión del presidio de la figura base, pero aumenta la multa de diez a treinta unidades tributarias mensuales además de eliminar la alternatividad entre presidio y multa y, como una innovación en el régimen de penas de este delito, añade la nueva pena accesoria de inhabilidad absoluta perpetua para la tenencia de cualquier tipo de animales ${ }^{49}$.

Por último, la figura agravada del inciso tercero, la pena será de presidio menor en su grado medio (esto es, de 541 días a 3 años de pena privativa de libertad), y multa de veinte a treinta unidades tributarias mensuales, además de la accesoria de inhabilidad absoluta perpetua para la tenencia de cualquier tipo de animales.

\subsubsection{Concursos}

Tras la nueva tipificación, al considerar al individuo animal como objeto material de este delito, es posible advertir pluralidad de delitos ahí donde sean varios animales afectados. En este sentido, MAÑALICH ha sostenido: "Bajo la tipificación hoy vigente, lo correcto será reconocer tantas instancias de realización del tipo como sean los animales individualmente afectados, en la forma de un concurso ideal, medial o real, según corresponda, como ello sucede, en general, tratándose de cualquier incidencia típicamente relevante en una pluralidad de personas individuales cuando el tipo en cuestión es el tipo de un delito contra un bien jurídico personalísimo. " 50 La situación descrita anteriormente se trataría de un concurso real, que se debe resolver bajo la regla de exasperación de la pena consagrada en el artículo 351 del Código Procesal Penal ${ }^{51}$.

\footnotetext{
${ }^{46}$ Esto cobra importancia para la persecución penal de actividades que hoy están siendo desacreditadas por la opinión pública, como por ejemplo el rodeo, sobre la cual si bien existe una autorización general en el artículo 16 de la Ley $\mathrm{N}^{\circ} 20.380$, es posible perseguir maltrato animal en los casos que se practique sin respeto a los reglamentos internos de esta actividad. Vid., VON MUHLENBROCK CANTALLOPTS, M., op. cit., pp. 228-233.

${ }^{47}$ LEIVA ILABACA, C., op. cit., p. 422.

${ }^{48}$ MESÍAS RODRÍGUEZ, J., op. cit., p. 82.

${ }^{49}$ Se abordará esta pena en el apartado 4.5 de este trabajo.

${ }^{50}$ MAÑALICH, J. P., op. cit., p. 324

51“Artículo 351.- Reiteración de crímenes o simples delitos de una misma especie. En los casos de reiteración de crímenes o simples delitos de una misma especie se impondrá la pena correspondiente a las diversas infracciones, estimadas como un sólo delito,
} 
Otras situaciones concursales que se han señalado son los concursos ideales ${ }^{52}$ entre maltrato animal e infracciones a actividades reguladas en las que se usa o intervienen animales como actividades, la caza, la pesca, la experimentación con animales vivos, los circos y las actividades veterinarias ${ }^{53}$ o entre maltrato animal y otros tipos penales como propagación indebida de agentes contaminantes del artículo 291, abigeato del artículo 488 bis y siguientes o el abuso sexual propio del artículo 356 bis que menciona la utilización de animales, todos delitos del Código Penal ${ }^{54}$.

Mención aparte requiere el concurso aparente de leyes penales. El concurso aparente ha sido definido por CURY como "cuando un hecho parece satisfacer las exigencias de dos o más tipos diversos, pero, en definitiva, solo será regulado por uno de ellos, en tanto que los demás resultarán desplazados por causas lógicas o valorativas" ${ }^{\text {"55. }}$. Para MATUS, esta institución jurídica poseería dos principios: non bis in idem, de carácter lógico-formal, del cual se desprenderían los criterios de especialidad, subsidiariedad y alternatividad y que tendrían en común que las normas concurrentes en el concurso aparente poseen cierta relación lógica entre ellas; y principio de insignificancia, de carácter valorativo, del cual se derivaría el criterio de consunción, que tiene como fundamento la inexistencia de relación lógica entre los preceptos involucrados en el concurso, debiendo preferirse aquella norma que absorbe la intensidad criminal de las otras ${ }^{56}$. El caso más claro de esto es el concurso aparente entre delito de maltrato animal y delito de daños simples del artículo 487 del Código Penal ${ }^{57}$. Así, MELLA ha propuesto que la regla para solucionar este concurso aparente sea la de especialidad, pues en el maltrato animal estaríamos frente a un "régimen punitivo específico", a diferencia del delito de daño $0^{58}$.

Ahora bien, de acuerdo con lo explicado sobre el concurso aparente, creo que esta solución no es la correcta pues ambos delitos protegen bienes jurídicos distintos: la propiedad, por un lado, y la salud y bienestar del animal, por el otro, no siendo posible advertir una relación lógica entre ambos. En atención a lo anterior y la creciente protección penal del animal no humano, que ha derivado en que se reconozca este bien jurídico de forma autónoma y personalísima, lo correcto es considerar que el delito de daño será sólo un "elemento acompañante" al delito de maltrato animal, siendo desplazado para castigar propiamente la afectación a la salud y bienestar del animal. Dicho de otra forma, este concurso aparente se resuelve aplicando el criterio de consunción, desplazando el delito de daño para castigar el delito maltrato animal por poseer una mayor intensidad criminal en el caso en concreto, así como también penas especiales para los fines que protege la norma, como la inhabilidad absoluta y perpetua para la tenencia de animales. Por otro lado, ya el artículo 488 del Código Penal reconoce que el delito de daño deberá ser desplazado en este caso al señalar que "Las disposiciones del presente párrafo solo tendrán lugar cuando el hecho no pueda considerarse como otro delito que merezca mayor pena".

\section{Delito de maltrato de animal en el APCP 3.1 Exposición del nuevo articulado}

El APCP, en su Título XII sobre los Delitos contra el orden público de su Libro II, regula el maltrato animal de la siguiente forma:

\section{"§3. Maltrato de animal Art. 461. Maltrato de animal.}

aumentándola en uno o dos grados.

$\mathrm{Si}$, por la naturaleza de las diversas infracciones, éstas no pudieren estimarse como un sólo delito, el tribunal aplicará la pena señalada a aquella que, considerada aisladamente, con las circunstancias del caso, tuviere asignada una pena mayor, aumentándola en uno o dos grados, según fuere el número de los delitos.

Podrá, con todo, aplicarse las penas en la forma establecida en el artículo 74 del Código Penal si, de seguirse este procedimiento, hubiere de corresponder al condenado una pena menor.

Para los efectos de este artículo, se considerará delitos de una misma especie aquellos que afectaren al mismo bien jurídico."

${ }^{52}$ El artículo 75 Código Penal regula el concurso ideal como: “el caso de que un sólo hecho constituya dos o más delitos, o cuando uno de ellos sea el medio necesario para cometer el otro.

En estos casos sólo se impondrá la pena mayor asignada al delito más grave."

${ }^{53}$ MELLA PÉREZ, R. A, op. cit., p. 165.

${ }^{54}$ LEIVA ILABACA, C., op. cit., p. 424.

${ }^{55}$ CURY URZUA, E., op. cit., p. 667.

${ }^{56}$ MATUS ACUÑNA, J. P., La teoría del concurso aparente de leyes penales y el "resurgimiento" de la ley en principio desplazada, en Revista De Derecho (Coquimbo). Año 9 (2002) 30-31.

57،Artículo 487. Los daños no comprendidos en los artículos anteriores serán penados con reclusión menor en su grado mínimo o multa de once a veinte unidades tributarias mensuales.

Esta disposición no es aplicable a los daños causados por el ganado y a los demás que deben calificarse de faltas, con arreglo a lo que se establece en el Libro tercero."

${ }^{58}$ MELLA PÉREZ, R. A, op. cit., p. 166.

142 Derecho Animal. Forum of Animal Law Studies, vol. 11/3 
El que sin razón suficiente infligiere grave dolor o sufrimiento a un animal vertebrado o a un cefalópodo será sancionado con libertad restringida o reclusión.

Art. 462. Maltrato grave de animal. La pena será libertad restringida, reclusión o prisión de 1 a 2 años para el que sin razón suficiente:

$1^{\circ}$ matare a un animal vertebrado o a un cefalópodo;

$2^{\circ}$ reiteradamente o por un largo tiempo infligiere grave dolor o sufrimiento a un animal vertebrado o a un cefalópodo.

Art. 463. Autorización legal y concurso. Tratándose del ganado, de animales empleados en la investigación científica o en la práctica de un deporte permitido por la ley o de animales recogidos o requisados por la autoridad sanitaria la autorización legal o conforme a la ley constituirá razón suficiente en el sentido de los dos artículos anteriores siempre que el dolor o el sufrimiento infligido al animal fueren racionalmente necesarios para el logro del fin permitido por la ley.

La pena establecida en los dos artículos precedente será aplicada sin perjuicio de la pena que correspondiere por el delito de daño."

Este artículo, así como el título correspondiente a los delitos contra el orden público, fueron elaboradas por el académico Juan Pablo Cox Leixelard, quien comparó las diversas disposiciones de dicho título de los Anteproyectos de 2013 y 2015, optando por mantener la regulación ya contenida en el Anteproyecto de 2013 con leves modificaciones ${ }^{59}$.

\subsection{Bien jurídico}

Lamentablemente, ni en la Carta de Presentación del APCP, así como tampoco en la Minuta para el análisis del Título XII se encuentra alguna explicación que permita esclarecer cuál sería el bien jurídico y la política-criminal que se adoptaría el prelegislador al consagrar este delito. No obstante, tratándose de un delito que se encuentra en un párrafo destinado exclusivamente a la protección jurídica-penal del animal no humano y de acuerdo con la evolución del bien jurídico brevemente expuesta, podemos señalar que el bien jurídico de este delito transitaría entre las posturas de bien jurídico colectivo (bienestar animal) o bien jurídico individual (bienestar y salud del animal no humano afectado) ya reseñadas.

En mi opinión, el bien jurídico de este delito debe ser la integridad física y psíquica del animal no humano, así como también su vida ${ }^{60}$, en cuanto bienes personalísimo. Estos bienes jurídicos se interpreta de acuerdo a la evolución de este delito y la protección del interés de no sufrir del animal no humano presente en la legislación chilena, así como también de la propia regulación propuesta en el APCP que castiga inflingir dolor, sufrimiento o la muerte.

\subsection{Tipo objetivo y subjetivo}

Del análisis de la regulación propuesta, se puede interpretar que la figura base del artículo 461 del APCP castiga al que inflige, sin razón suficiente, de forma ocasional, grave dolor o sufrimiento a un animal vertebrado o a un cefalópodo, sin causarle la muerte.

El verbo rector del delito es "infligir", el cual, en un sentido natural, se puede interpretar como "causar daño", lo que permite comprender tanto una modalidad comisiva como omisiva de este delito, esto último siempre que exista posición de garante tal como se ha señalado. La sustitución del actual verbo rector "actos de maltrato y crueldad" por este nuevo verbo "infligir" permitiría modelar de mejor forma la conducta ilícita, ante la ambigüedad y amplitud de los primeros conceptos, sin perjuicio de que este problema fue zanjado al incorporarse la definición de dicho verbo rector con la introducción del 291 ter del Código Penal por la Ley $\mathrm{N}^{\circ} 21.020$, al definir "actos de maltrato y crueldad" como causar daño, dolor o sufrimiento.

Este delito, en cuanto a los sujetos activos y pasivos, no hay mayor diferencia con la actual regulación, por lo que nos podemos remitir a lo planteado en el punto 2.2.1.

En cuanto al objeto material, estos serán los “animales vertebrados o cefalópodos”. En un sentido natural, de acuerdo con la Real Académica Española, animal vertebrado es aquel "del grupo de los cordados que tiene esqueleto con columna vertebral y cráneo, y sistema nervioso central constituido por médula espinal y encéfalo", y cefalópodo sería un molusco marino "que tiene el manto en forma de saco con una abertura

\footnotetext{
${ }^{59}$ Minuta para el análisis del Título XII del Libro Segundo, p. 26. En línea en: https://www.minjusticia.gob.cl/media/2018/10/CoxJuan-Pablo-Delitos-contra-el-orden-p\%C3\%BAblico.pdf [último acceso el 21 de septiembre de 2020].

${ }^{60}$ En este sentido también se ha manifestado Ríos CORBACHO a propósito del tipo penal de maltrato animal de España. Vid., RÍOS CORBACHO, J. M., Nuevos tiempos para el delito de maltrato de animales a la luz de la reforma del Código Penal español (LO 1/2015), en Revista electrónica de ciencia penal y criminología, 18 (2016) 25-28.
} 
por la cual sale la cabeza, que se distingue bien del resto del cuerpo y está rodeada de tentáculos largos provistos de ventosas". De esta forma, se ampliaría el objeto material a otros animales no humanos que actualmente no serían contemplados por la doctrina a la hora de interpretar el objeto material del presente delito.

Respecto al resultado típico, este tipo penal conserva los conceptos de "dolor" y "sufrimiento" contemplados en la actual regulación, ante lo cual podemos señalar que se tratarían de resultados que afecten a la integridad física y psíquica del animal no humano, respectivamente. Esta idea se puede corroborar también en la explicación que da el prelegislador sobre esta disposición, al señalar que se conservó la regulación del Anteproyecto de 2013, en lugar de aquella propuesta por su versión del año 2015, pues no habría razones para excluir el sufrimiento no corporal, cuestión que realizaba dicho Anteproyecto ${ }^{61}$. Ahora bien, este tipo penal exige expresamente que este resultado sea "grave", es decir, que se trate de un dolor o sufrimiento de gran entidad o importancia, dando espacio al juez para determinar qué dolor o sufrimientos revestirán la característica de gravedad exigida. Para estos efectos, puede resultar ilustrativo la doctrina del Tribunal Supremo Español ${ }^{62}$, que, a propósito del tipo penal español, ha definido "grave menoscabo" haciendo un parangón con los tipos penales de lesiones. Así, se exigiría que la entidad del resultado hiciera necesario que el animal requiera tratamiento médico veterinario para su recuperación y que este tratamiento sea de intensidad, es decir, que no se agote en una sola consulta y tenga cierta periodicidad; también evaluar si se hospitalizó o no al animal no humano; que éste haya sido imposibilitado para realizar actividades propias de su especie; el riesgo vital que conllevó este menoscabo; y las secuelas o padecimientos permanentes.

Por último, el tipo subjetivo de este delito no genera mayores problemas interpretativos pues de la descripción se desprende que sólo se castiga el maltrato de animal doloso, lo cual se satisface con la concurrencia -a lo menos- de dolo eventual, manteniendo el mismo tratamiento que la actual tipificación.

En cuanto al tipo penal del artículo 462 del APCP, se trata de una figura agravada por el resultado: en el numeral $1^{\circ}$, se exige causar la muerte al animal vertebrado o cefalópodo, esto es, quitar la vida; en el numeral $2^{\circ}$, por su parte, se exige que el grave dolor o sufrimiento sea reiterado o prolongado en el tiempo, esto sería, que no sea realizado por un acto ocasional. Por lo tanto, sólo en caso de causación de muerte o de reiteración, estaríamos en la figura de maltrato grave que contempla el artículo 462 del APCP.

\subsection{Antijuridicidad}

La frase "sin razón suficiente" podemos interpretar que se referiría a la antijuridicidad, lo cual se puede colegir de forma análoga a la actual voz "injustificadamente". Sobre la interpretación de esto, nos remitimos a lo expuesto en el punto 2.2.3 de este trabajo. Por otro lado, el artículo 463 hace una referencia a ciertos casos en que existiría razón suficiente o justificabilidad, en el sentido de aquellas conductas con causales de justificación especial referidas al trato con el animal, cuestión ya explicada precedentemente.

\subsection{Penalidad}

Las penas para el delito del artículo 461 del APCP son libertad restringida o reclusión, cuya extensión se rige de acuerdo con las normas de los artículos 49 y 50 del APCP; por su parte, el delito del artículo 462 del APCP tiene penas de libertad restringida, reclusión o prisión de uno a dos años.

La libertad restringida, según el artículo 50 del APCP, se impone al condenado a un régimen de control ambulatorio de su desempeño cotidiano acompañado de aquellas prohibiciones, obligaciones, condiciones, actividades y programas que se hayan definido en un plan de cumplimiento individual, el cual deberá ser aprobado por el tribunal y estará orientado a fortalecer el respeto del condenado por los derechos de las demás personas y a favorecer condiciones para que no vuelva a perpetrar delitos en el futuro. La duración de esta pena será de seis meses y una duración máxima de dos años.

Por otro lado, la reclusión, según el artículo 49 del APCP, es la privación de libertad del condenado mediante su encierro en su morada o un establecimiento público destinado especialmente para ello bajo las modalidades de diurna, nocturna o de fin de semana. La duración de esta pena será de seis meses y una duración máxima de dieciocho meses.

Por último, la prisión según el artículo 48 del APCP es la privación de libertad del condenado mediante su encierro en un establecimiento público especialmente destinado a ello.

\footnotetext{
${ }^{61}$ Minuta para el análisis del Título XII del Libro Segundo, p. 26. En línea en: https://www.minjusticia.gob.cl/media/2018/10/CoxJuan-Pablo-Delitos-contra-el-orden-p\%C3\%BAblico.pdf [último acceso el 21 de septiembre de 2020].

${ }^{62}$ Vid., MORADELL ÁVILA, J., Malos tratos a los animales. Doctrina del Tribunal Supremo, en Boletín Intercids de Derecho Animal, Julio/Agosto (2020) 1-12. 


\section{Consideraciones del proyecto \\ 4.1 Consideraciones en general}

En atención a las evidentes diferencias en la redacción del tipo penal de maltrato de animal expuesta en el APCP respecto a su actual regulación en los artículos 291 bis y ter del Código Penal, podemos señalar los siguientes elementos en los cuales, en mi opinión, la regulación propuesta implica un retroceso y no innova en materias que son criticables a la regulación actual:

- Exigencia de gravedad en el resultado típico.

- Delimitación del animal no humano protegido.

- Ausencia de otros tipos penales y/o agravantes.

- Eliminación de pena de inhabilidad para la tenencia.

- Omisión de medidas para resguardar a los animales afectados.

\subsection{Exigencia de gravedad en el resultado típico}

El tipo básico delimita el delito de maltrato de animal a aquellos resultados de "grave dolor o sufrimiento". De esta forma, aquel dolor o sufrimiento que no sea grave no será punible en los términos de este delito. Esta exigencia típica indica de forma considerable qué maltrato será considerado hecho punible, lo que implica una disminución en la protección penal que recibe por parte del Estado el animal no humano.

En este punto, el APCP opta por renunciar a delimitar claramente qué actos u omisiones constituirían este delito y delegaría al juez la tarea de interpretar qué conducta que inflija dolor o sufrimiento será de aquella gravedad exigida por el tipo penal. De este modo, habría una contradicción evidente entre la salvaguarda del bien jurídico protegido por esta norma y la regulación de este delito, pues se excluiría la punición de atentados al bienestar, salud e integridad del animal no humano en base a esta exigencia.

\subsection{Delimitación del animal no humano protegido}

Tal como se expuso, el objeto material (o sujeto pasivo) de este delito no es cualquier animal no humano, pues quedan excluidos de ella los animales invertebrados con la excepción de los cefalópodos. Es llamativo que el APCP haga esta distinción pues ni la ley sobre protección animal la realiza a la hora de establecer qué los animales son seres dotados de sensibilidad.

Nuevamente nos encontramos ante una ausencia de fundamentación en esta decisión en los documentos que acompañan al APCP, por lo que no tenemos ninguna referencia de los motivos de política-criminal para esta delimitación. No obstante, ya se ha advertido que la actual redacción del artículo 291 bis del Código Penal protegería -a lo menos- a animales vertebrados ${ }^{63}$, lo cual encontraría su fundamento en el reconocimiento de la conciencia y capacidad de sentir experiencias subjetivas, tanto positivas como negativas de estos animales no humanos ${ }^{64}$. Estimo que esto pudo ser lo que el redactor de este articulado tuvo en cuenta a la hora de la mencionada delimitación.

Ahora bien, esta delimitación hace de este tipo penal un tipo bastante rígido en cuanto a considerar qué animal no humano poseería aquellas características relevantes para obtener protección por parte del Derecho penal, cuestión que debería ser dejada a la ciencia y a los avances de los estudios sobre el sufrimiento animal.

\subsection{Ausencia de otros tipos penales y agravantes}

Existen distintas formas de maltrato animal que guardan un disvalor especial en atención a su relevancia práctica y criminológica, las cuales en el APCP no se abordarían expresamente. Así, podemos señalar las siguientes, que bien podrían constituir tipos penales autónomos o agravantes:

- Abandono de animales. De acuerdo con el artículo 12 de la Ley $N^{\circ} 21.020$, el abandono de animales se equipara al delito de maltrato. Ahora bien, la discusión de un nuevo código punitivo puede ser la posibilidad de dotar de mayor autonomía a dicho figura delictiva e incluso diferenciar entre abandono con consecuencias contra la integridad o vida del animal de aquel sin consecuencias. En esta regulación no hay mención a ello y no vemos razones para omitirla en un país con altas cifras

\footnotetext{
${ }^{63}$ Sobre este punto, me remito al análisis del objeto material de la actual regulación en el apartado 2.2.1 de este trabajo.

${ }^{64}$ Esta tendencia ha adquirido fuerza tras la célebre Declaración de Cambridge sobre la Conciencia el 7 de julio año 2012. En línea: https://www.animal-ethics.org/declaracion-consciencia-cambridge/ [último acceso el 21 de septiembre de 2020].
} 
de abandono de animales de compañía ${ }^{65}$. Así las cosas, el APCP iría en contra de la tendencia político-criminal de castigar el abandono de animales, que podemos encontrar en nuestra legislación, como también en la española, quienes incluyeron esta figura en el artículo 337 bis del Código Penal español tras la reforma de la LO 1/2015. Estimo que habría sido útil tomar esta última legislación de referencia para abordar esta temática, pues en el delito de abandono de animales de España, se castiga "abandonar en condiciones en que pueda peligrar la vida o integridad del animal", siendo este un delito de peligro y se ha interpretado dicha figura delictual como dejar en situación de desamparo a un animal, ya sea por acción (expulsión del hogar o albergue) o por omisión (incumplimiento de deberes de garante) ${ }^{66}$, esto a diferencia de nuestra actual regulación que no delimita el delito de abandono de animales, por lo que situaciones de simple abandono, que no poseen la potencialidad de lesionar el bien jurídico de esta norma, también podrían subsumirse en dicho delito.

- Violencia sexual contra animales. Si bien actualmente no está regulado expresamente en el artículo 291 bis del Código Penal, existen razones criminológicas y de política-criminal para regular la violencia sexual contra animales no humanos. Desde la criminología norteamericana, se ha conceptualizado este tipo de hechos como "abusos sexuales interespecie", estudiándose la fenomenología de los actos de bestialismo señalando que en ningún caso podrían ser estos justificados en cuanto a lo siguiente: en la generalidad de estos casos hay violencia, estas prácticas generan sufrimiento, dolor, estrés e incluso la muerte, y no hay una posibilidad efectiva de entender un consentimiento implícito por parte del animal no humano ${ }^{67}$. Este tema ha sido abordado en España en el delito de maltrato animal del artículo 337.1, al señalar dentro del maltrato animal "sometiéndole a explotación sexual", sin perjuicio que esta fórmula tiene un alcance restringido ${ }^{68}$. En nuestro medio, diversas iniciativas parlamentarias han buscado castigar la zoofilia y los actos bestialismo, siendo la última de estas el proyecto de ley Boletín $\mathrm{N}^{\circ} 12822-07$ que "Modifica el Código Penal para tipificar como delito la zoofilia" de 2019, ante la Cámara de Diputadas y Diputados de Chile, y que sanciona con las mismas penas del inciso tercero del artículo 291 bis a quien "acceda carnalmente o introdujere objetos por vía vaginal, anal o bucal a un animal, así como cualquier otro acto de significación sexual, sin considerar su especie o raza". Adicionalmente, esta reforma al delito de maltrato animal puede ser la oportunidad para incorporar figuras como la facilitación, inducción, promoción o comercialización de abusos sexuales interespecie, lo cual en nuestro medio ha sido propuesto en el proyecto de ley Boletín $\mathrm{N}^{\circ} 10.895-07$ que "Modifica diversos cuerpos legales relativos a delitos que afectan a los animales para otorgarles una efectiva protección en materia penal" presentado en la cámara baja, el año 2016.

- Agravantes. Tanto en las propuestas legislativas de nuestro país como en legislación comparada existe una serie de circunstancias agravantes a considerar en el delito de maltrato animal por el mayor riesgo que estas conllevarían para la integridad, salud y vida del animal. Así, siguiendo el artículo 337.2 del Código Penal español, se puede considerar el uso de armas, el ensañamiento y la pérdida o la inutilidad de un sentido, órgano o miembro. En atención a que hay formas que generan un perjuicio o riesgo mayor al animal no humano afectado, estimo que hay razones suficientes para incluirlas como agravantes y dotarlo así de una mejor protección penal.

\subsection{Eliminación de la pena de inhabilidad para la tenencia}

Uno de los grandes avances de las reformas de la Ley $\mathrm{N}^{\circ} 21.020$ introducidas al delito de maltrato

\footnotetext{
${ }^{65}$ La información más actualizada arrojaría la cifra de 343.000 perros y gatos "sin dueño" a lo largo de Chile. CCN Chile (2018): Más de 343 mil perros $y$ gatos sin dueño circulan por las calles y zonas rurales de Chile Recuperando de: https://www.cnnchile.com/pais/mas-de-343-mil-perros-y-gatos-sin-dueno-se-registran-en-chile_20181114/[último acceso el 21 de septiembre de 2020].

${ }^{66}$ MESÍAS RODRÍGUEZ, J., op. cit., pp. 85-86.

${ }^{67}$ Vid., BEIRNE, P., Rethinking Bestiality: Towards a concept of interspecies sexual assault, en Theoretical Criminology, 1/3 (1997) 317-340, quien propone reemplazar el uso del término "bestiality" por el de "interspecies sexual assault" en atención al paralelismo de estas conductas con el abuso sexual contra niños o niñas pues (1) en la interacción sexual humano-animal casi siempre hay coerción, (2) estas prácticas frecuentemente generan dolor e incluso la muerte y (3) los animales son incapaces de comunicarse con nosotros, por lo que difícilmente podrían "consentir" con estos encuentros sexuales. Este concepto sería más amplio que violación, abarcando un amplio espectro de conductas más allá del acceso carnal por vía oral, vaginal o anal del animal.

${ }^{68} \mathrm{Se}$ ha dicho que tras el concepto de "explotación", se hallaría la necesidad de un ánimo de lucro, lo cual estaría incluso refrendado por la jurisprudencia del Tribunal Supremo español por lo que no cualquier abuso de naturaleza sexual sería castigado bajo esta figura. Vid., MESÍAS RODRÍGUEZ, J., op. cit., pp. 83-84.
} 
animal fue el establecimiento de la pena de inhabilidad perpetua para la tenencia de animales. En esta nueva regulación, no se hace mención alguna a esta inhabilidad como pena especial de este delito, tampoco se menciona como una de las consecuencias adicionales a la pena que establece el artículo 129, ni menos se incluye en el catálogo de "Inhabilidades y Prohibiciones" contenido en el párrafo $5^{\circ}$ del Título VII del Libro I del APCP.

Esta omisión es un retroceso importante en cuanto a que, en mi opinión, se trataría de una medida de carácter punitivo que persigue un fin preventivo-especial, evitando que el condenado de este maltrato ponga en riesgo nuevamente el bien jurídico protegido por esta norma ${ }^{69}$. Esta reforma pudo ser una oportunidad para ampliar esta inhabilidad a situaciones que actualmente no abarca, como convivir o trabajar con animales ${ }^{70}$, lo cual también ha sido advertido en el proyecto de ley Boletín $\mathrm{N}^{\circ} 10.895-07$ ya mencionado.

\subsection{Omisión de medida para resguardar a los animales afectados}

Al igual que la actual regulación de este delito, la propuesta del APCP no hace mención al retiro, rescate o comiso de animales no humanos que hayan sido afectados por este delito y que sean de propiedad del condenado. A modo de contexto, si bien no está regulado el comiso como una consecuencia accesoria del delito de maltrato animal, en la actual regulación se establece una medida cautelar especial para estos delitos en el artículo 12 letra a) de la Ley $\mathrm{N}^{\circ} 20.380$, el cual señala que el juez podrá "ordenar que los animales afectados sean retirados del poder de quien los tenga a su cargo para ser colocados al cuidado de una persona natural o jurídica que se designe al efecto"; luego, en caso de condena, si se trata de uno de los casos de los incisos $2^{\circ}$ y $3^{\circ}$ del artículo 291 bis del Código Penal, la imposición de la inhabilidad para la tenencia de animales permitiría en la práctica evitar que los animales no humanos afectados vuelvan al dominio del maltratador ante la imposibilidad de éste de la tenencia de aquellos.

En los hechos, la laguna legal que nos deja la ausencia del retiro o comiso de animales como consecuencia de este delito genera situaciones complejas a aquellas organizaciones de protección animal que cuidan en calidad de depositarios provisionales a un animal no humano maltratado y que, en el caso hipotético de finalizar un juicio en cuyo resultado no se aplique la inhabilidad para tenencia, se verían obligadas a devolverlos al condenado. Por lo demás, estas organizaciones deben acatar dicha obligación o, de lo contrario, los representantes legales de aquellas incurrirían en los delitos de depositario alzado o apropiación indebida.

El APCP no contempla una figura relacionada al retiro o comiso del animal en el tipo penal revisado, por lo que habrá que analizar las reglas generales. Así, el comiso en este cuerpo normativo está regulado en el Título VII del Libro I, el cual aborda las consecuencias adicionales a la pena. De acuerdo con el artículo 129 del APCP, existirían dos tipos de comiso: de los instrumentos y efectos del delito y de las ganancias asociadas al mismo, los cuales son definidos de la siguiente forma:

"Art. 130. Comiso de instrumentos y efectos. Por el comiso de instrumentos y efectos se priva a una persona de la propiedad sobre las cosas que hubieren sido usadas como instrumentos en la perpetración del delito o que hubieren sido obtenidas o producidas a través de su perpetración y se la transfiere al Estado.

Art. 131. Comiso de ganancias. Por el comiso de ganancias se priva a una persona de activos patrimoniales cuyo valor corresponda a la cuantía de las ganancias obtenidas a través del delito o asociadas a él y se los transfiere al Estado."

De estas definiciones, se desprende que el comiso como consecuencia adicional a la pena no contemplaría el retiro de los animales no humanos afectados por este delito, pues estos no han sido usados como instrumentos para cometerlo, no son obtenidos tras su comisión, ni menos se podría hablar de que son una ganancia del delito. De este modo, se mantiene el problema que actualmente posee este delito, que podemos resumir en el siguiente supuesto: una persona, al ser condenada por maltratar a su animal de compañía, tras finalizar el juicio, podrá recobrar la tenencia de éste, poniéndose en riesgo nuevamente la integridad del animal no humano afectado ${ }^{71}$.

${ }^{69}$ BINFA ÁLVAREZ. J., Sobre la pena accesoria de inhabilidad absoluta perpetua para tenencia de animales a propósito de un caso de maltrato animal. Borrador $\mathrm{s} / \mathrm{f}$.

${ }^{70}$ LEIVA ILABACA, C., op. cit., p. 422.

${ }^{71}$ Este mismo problema se plantearía en la regulación española del delito de maltrato animal en los artículos 337 y 337 bis del Código Penal español, pues ni los tipos penales ni el artículo 127 que regula las consecuencias accesorias de los delitos contemplan una medida al respecto. Sobre esto último, vid, OLMEDO DE LA CALLE, E., La intervención o decomiso del animal objeto del delito, en Boletín Intercids de Derecho Animal, Octubre 2018, pp. 1-11, quien advierte que este tipo de consecuencias iría en contra del bien jurídico protegido en los delitos de maltrato animal, por lo que propone una interpretación lógica y sistemática que incluya al animal no humano como "mero efecto del delito" teniendo presente: (1) que en la regulación administrativa sobre protección de animales se permite la 


\section{Propuestas de regulación}

Durante el proceso de discusión del APCP, se presentó este proyecto a diversas Facultades de Derecho del país, las cuales entregaron al Ministerio de Justicia y Derechos Humanos durante 2018 sus comentarios, sugerencias y propuestas. En este proceso han participado once Universidades distintas hasta la fecha.

Sobre el delito de maltrato de animal, sólo los cuerpos académicos de la Universidad Adolfo Ibáñez y la Universidad de Chile lo abordaron. A continuación, se expondrán ambas propuestas y se dejará para el apartado de las conclusiones la valoración de ambas.

\subsection{Propuesta de la Universidad Adolfo Ibáñez}

Sobre el delito de maltrato de animal, las observaciones de la Facultad de Derecho de la Universidad Adolfo Ibáñez estuvieron a cargo del profesor de Derecho Constitucional Javier Gallego ${ }^{72}$, quien sostuvo que debía tener en consideración la actual regulación de maltrato animal y el proyecto de ley Boletín $\mathrm{N}^{\circ} 10.895$ 07 ya mencionado, en atención a que incluye una pena accesoria de inhabilidad, e incluiría una hipótesis relacionada a violencia sexual contra el animal.

De este modo, el articulado propuesto por esta casa de estudios es el siguiente:

“Art. 461. Maltrato de animal. El que sin razón suficiente infligiere grave dolor o sufrimiento, o ejecutare actos de abuso sexual o acceso carnal a un animal vertebrado o a un cefalópodo será sancionado con libertad restringida o reclusión, pudiendo el juez imponer además la pena de inhabilitación especial para el ejercicio de profesión, oficio o comercio que tenga relación con animales y para su tenencia, asi la como inhabilitación para la convivencia con ellos en el mismo domicilio.

El abandono de un animal de compañía será considerado maltrato, en los términos del inciso primero. Si del abandono resultare la muerte del animal, el acto será considerado maltrato grave ${ }^{73}$."

\subsection{Propuesta de la Universidad de Chile}

En el informe de la Facultad de Derecho de la Universidad de Chile, se propone que este delito "debería concordar con la legislación actual al respecto (ley 21.020)", incorporando dos incisos al artículo 461 para estos efectos $^{74}$. Debido a lo anterior, el articulado propuesto por esta casa de estudios es el siguiente:

"Art. 461. Maltrato de animal. El que sin razón suficiente infligiere grave dolor o sufrimiento a un animal vertebrado o a un cefalópodo será sancionado con libertad restringida o reclusión.

Si el hecho fuere perpetrado con extrema crueldad hacia el animal afectado, se tendrá por concurrente una agravante calificada o muy calificada.

Con la misma pena prevista en el inciso primero se sancionará a quien hiciere abandono de un animal vertebrado o un cefalópodo que hubiere mantenido como mascota en el propio espacio doméstico, poniéndolo en situación de grave desamparo. ${ }^{75}$ ",

\section{Conclusiones}

medida de "decomiso definitivo"; (2) la finalidad del decomiso es proteger determinados bienes jurídicos y, en este caso, el animal no humano se ve beneficiado con el bien jurídico protegido en el maltrato animal; (3) no tendría sentido privar al imputado provisionalmente de la posesión del animal mientras dure el procedimiento para, una vez condenado, devolverle dicha posesión; y (4) se debe tener presente la existencia de aquella normativa vigente que establecería como principio básico la evitación de sufrimientos innecesarios. Ahora bien, creo que esta interpretación pasa por alto el principio de legalidad que en su formulación tradicional de "nullum crimen nulla poena sine previa lege" se traduciría en un mandato de determinar legalmente las penas y delitos y en Chile el comiso es una pena de acuerdo con el artículo 21 del Código Penal y claramente el animal no humano no está considerado como "mero efecto" del delito. No obstante, al igual que en la jurisprudencia española, los tribunales en Chile utilizan el comiso para apartar al animal no humano afectado por el delito sin realizar una mayor fundamentación de su procedencia o regulación.

${ }^{72}$ Informe Anteproyecto Código Penal Universidad Adolfo Ibáñez, pp. 63-64

https://www.minjusticia.gob.cl/media/2018/12/UAI_Informe_AnteproyectoCodigoPenal2018.pdf [último acceso el 21 de septiembre de 2020].

${ }^{73}$ Informe Anteproyecto Código Penal Universidad Adolfo Ibáñez, p. 63. En línea en:

https://www.minjusticia.gob.cl/media/2018/12/UAI_Informe_AnteproyectoCodigoPenal2018.pdf [último acceso el 21 de septiembre de 2020].

${ }^{74}$ Informe Anteproyecto Código Penal Universidad de Chile, p. 18. En línea en:

https://www.minjusticia.gob.cl/media/2018/12/UChile_Informe_AnteproyectoCodigoPenal2018.pdf [último acceso el 21 de septiembre de 2020].

${ }^{75}$ Ibid. p. 18.

148 Derecho Animal. Forum of Animal Law Studies, vol. 11/3 
1. El maltrato animal y la protección penal del animal no humano son problemas que nuestra sociedad ha venido interiorizando cada vez con más fuerza y que en las últimas décadas ha tenido una importante evolución legislativa. Si bien la regulación del delito de maltrato animal ha avanzado tras las modificaciones introducidas por la Ley $\mathrm{N}^{\circ} 21.020$, todavía falta camino por recorrer para asegurar una mejor tutela de los intereses de los animales no humanos que requieran de protección penal.

2. La discusión de un nuevo código punitivo es una gran oportunidad para repensar cómo le otorgamos protección penal a los animales no humanos. En este orden de ideas, la propuesta del APCP, en mi opinión, es un retroceso para estos fines, pues termina estableciendo una figura delictiva que reduce significativamente qué casos serán considerados como maltrato, y que, además, no cuenta con medidas accesorias que servirían para fines preventivos y, de este modo, proteger de mejor forma a los animales no humanos de potenciales agresiones a su salud e integridad. Hay dos motivos para explicar esto: o la política-criminal adoptada por el prelegislador tiende a la descriminalización del delito de maltrato animal, o simplemente no tuvo como fuente su actual regulación, como tampoco los proyectos de ley que buscan mejorar la mismo con los mencionados boletín $\mathrm{N}^{\circ} 10.895-07$ y $\mathrm{N}^{\circ}$ 12.822-07 u otras legislaciones como la española cuyo desarrollo doctrinario, ha sido importante en el último tiempo. No obstante, se valora que la redacción de este tipo penal en el APCP presente una mejor técnica legislativa que la actual regulación, superando conceptos ambiguos y vagos como "actos de maltrato y crueldad" que han caracterizado a este delito en nuestra tradición jurídica.

3. Si bien ya existen propuestas realizadas por académicos para robustecer el delito de maltrato animal en el APCP, siendo la propuesta realizada por el profesor Javier Gallegos bastante completa y concordante con la actual regulación de este delito, llama la atención que ambas insisten en delimitar el maltrato a causar resultados de carácter grave, lo cual se aparta de nuestra actual regulación que no exige dicha gravedad en el resultado típico, y que tampoco contemplen los resultados de lesiones que menoscaben gravemente la integridad del animal o la causación de muerte. Además, ambas propuestas no contemplan mejoras para aquellos aspectos que he reseñado como necesarios para avanzar en la protección penal del animal no humano.

4. Por otro lado, llama la atención que las sanciones para este delito en la regulación propuesta por el APCP, sólo sean penas restrictivas o privativas de libertad, omitiendo la pena accesoria de inhabilidad contemplada en la actual regulación. Esta pudo haber sido la oportunidad para establecer, como consecuencia de este delito, el retiro del animal no humano, ordenando su ingreso a un refugio de animales o a un centro de mantención temporal. También, pudo haber sido la oportunidad para imponer como medida accesoria la obligación la asistencia a programas terapéuticos sobre control de impulsos, abuso, violencia y/o protección animal, medidas que se contemplan tanto en el boletín $\mathrm{N}^{\circ}$ 10.895-07 y en el artículo 83.1.6 del Código Penal español.

5. Una regulación moderna del delito de maltrato animal debe explorar la creación de nuevos tipos penales y figuras agravadas para estar en sintonía con los avances científicos en materias de medicina veterinaria y etología, neurociencia, sociología, criminología e incluso psicología y psiquiatría que revelan la importancia de esta temática, tanto por la sensibilidad social que genera, la afectación a la integridad y salud del animal no humano y también por la importancia de reconocer los interés. Si como sociedad nos tomamos en serio el combate contra las violencias, debemos ser conscientes de cada una de ellas y considerar vínculo estrecho entre la violencia contra los animales no humanos y la violencia hacia los humanos, así como también de las repercusiones nocivas de ésta para la sociedad. De este modo, debemos contar con herramientas jurídicas eficaces a la hora de poder prevenir actos de violencia, castigarlos y resocializar a quienes la cometen.

\section{Bibliografía}

- BEIRNE, P., Rethinking Bestiality: Towards a concept of interspecies sexual assault, en Theoretical Criminology, 1/3 (1997) 317-340. https://doi.org/10.1177/1362480697001003003 BINFA ÁLVAREZ. J., Sobre la pena accesoria de inhabilidad absoluta perpetua para tenencia de animales a propósito de un caso de maltrato animal. Borrador s/f.

- CURY URZUA, E., Derecho penal parte general (Santiago 2010). 
- DE LAS HERAS CRUZ, J., El bienestar animal como bien jurídico-penal, en CHIBLE VILLADANGOS, M. y GALLEGO SAADE, J. (eds.): Derecho animal teoría y práctica (Santiago, 2018) 185-222.

- LEIVA ILABACA, C., El delito de maltrato animal en Chile: Historia del artículo 291 bis y análisis crítico a la luz del nuevo tipo penal incorporado por la Ley $\mathrm{N}^{\circ} 21.020$, en CHIBLE VILLADANGOS, M. y GALLEGO SAADE, J. (eds.): Derecho animal teoría y práctica (Santiago 2018) 405-426.

- GUZMAN DÁlBORA, J., El delito de maltrato de animales, en Estudios Penales (Santiago 2009) 241-295.

- MAÑAliCH, J. P., Animalidad y Subjetividad. Los animales (no humanos) como sujetos-dederecho, en Revista de Derecho (Valdivia) 31/2 (2018) 321-337.

- MATUS ACUÑA, J. P., La teoría del concurso aparente de leyes penales y el "resurgimiento" de la ley en principio desplazada, en Revista De Derecho (Coquimbo). Año 9 (2002) 27-68.

- MELLA PÉREZ, R. A, Evolución jurisprudencial del delito de maltrato o crueldad animal en Chile, en dA. Derecho Animal (Forum of Animal Law Studies) 9/3 (2018) 147-176.

- MESÍAS RODRÍGUEZ, J., Los delitos de maltrato y abandono de animales en el Código Penal español, en dA. Derecho Animal (Forum of Animal Law Studies) 9/2 (2018) 66-105.

- MONTES FRANCESCHINI, M., Derecho animal en Chile (Santiago 2018).

- MORADELl ÁVILA, J., Malos tratos a los animales. Doctrina del Tribunal Supremo, en Boletín Intercids de Derecho Animal, Julio/Agosto (2020) 1-12.

- OLMEDO DE LA CALLE, E., La intervención o decomiso del animal objeto del delito, en Boletín Intercids de Derecho Animal (Octubre 2018) 1-11.

- RÍOS CORBACHO, J. M., Nuevos tiempos para el delito de maltrato de animales a la luz de la reforma del Código Penal español (LO 1/2015), en Revista electrónica de ciencia penal y criminología, 18 (2016) 1-55.

- TAPIA THENOUX, M. F., El Estatus jurídico y moral del animal no-humano. (Santiago 2020).

- VON MUHLENBROCK CANTALLOPTS, M., Rodeo y maltrato animal, en MATUS ACUÑA, J. P., (dir.): Derecho penal del medio ambiente chileno (Valencia 2019) 213-241.

- WILENMANN VON BERNATH, J., Causación lícita de lesiones o de la muerte de animales en el sistema jurídico chileno tras la Ley $\mathrm{N}^{\circ} 21.020$, en CHIBLE VILLADANGOS, M. y GALLEGO SAADE, J. (eds.): Derecho animal teoría y práctica (Santiago 2018) 427-452.

\section{Jurisprudencia}

- Sentencia Segundo Tribunal Oral en lo Penal de Santiago de 26/2/2020, RIT 314-2019.

- Sentencia Séptimo Tribunal Oral en lo Penal de Santiago de 21/12/2019, RIT 277-2019.

- Sentencia Tribunal Oral en lo Penal de Valparaíso de 12/10/2018, RIT 490-2017.

- Sentencia Tribunal Oral en lo Penal de San Antonio de 13/8/2018, RIT 207-2017.

\section{Legislación}

\section{Chile}

- Código Civil publicado el 14/12/1855.

- Código Penal publicado el 12/11/1874.

- Código Procesal Penal publicado el 12/10/00.

- Ley $\mathrm{N}^{\circ} 18.859$ publicada el 29/11/1989.

- Ley $\mathrm{N}^{\circ} 20.380$ publicada el 3/11/2009.

- Ley $\mathrm{N}^{\circ} 21.020$ publicada el 2/8/2017.

- Reglamento Decreto 1007 del Ministerio del Interior y Seguridad Pública publicado el 17/8/2018.

- Reglamento Decreto 1 del Ministerio de Salud publicado el 29/1/2014.

\section{España}

- Código Penal publicado el 24/11/1995.

\section{Otras fuentes}




\section{Sitios web}

- CCN Chile (2018): Más de 343 mil perros y gatos sin dueño circulan por las calles y zonas rurales de Chile. En línea: https://www.cnnchile.com/pais/mas-de-343-mil-perros-y-gatos-sin-dueno-seregistran-en-chile_20181114/.

- National Link Coalition. En línea: https://nationallinkcoalition.org/.

- Ministerio de Justicia y Derechos Humanos, Anteproyecto para Nuevo Código Penal de 2013. En línea: https://www.minjusticia.gob.cl/anteproyecto-para-nuevo-codigo-penal/anteproyecto-codigopenal-2013/.

- Ministerio de Justicia y Derechos Humanos, Anteproyecto para Nuevo Código Penal de 2015. En línea: https://www.minjusticia.gob.cl/anteproyecto-para-nuevo-codigo-penal/anteproyecto-codigopenal-2015/.

- Ministerio de Justicia y Derechos Humanos, Anteproyecto para Nuevo Código Penal de 2018. En línea: https://www.minjusticia.gob.cl/anteproyecto-para-nuevo-codigo-penal/.

- Policía de Investigaciones - Aumentan investigaciones por maltrato animal. En línea: https://www.pdichile.cl/centro-de-prensa/detalle-prensa/2019/02/15/aumentan-investigacionespor-maltrato-animal.

\section{Documentos}

- Anteproyecto de Nuevo Código Penal (2005). En Línea: http://www.icpenales.cl/website/www.icpenales.cl/uploads/pdf/anteproyecto-foro-penal.pdf.

- Anteproyecto de Código Penal (2018). En línea: https://www.minjusticia.gob.cl/media/2018/10/Anteproyecto_de_C\%C3\%B3digo_Penal_2018.pdf

- Carta de Entrega de Anteproyecto de Código Penal dirigida al Ministro de Justicia y Derechos Humanos, don Hernán Larraín Fernández, de fecha 17 de octubre de 2018. En línea: https://www.minjusticia.gob.cl/media/2018/10/Carta-entrega-Anteproyecto-de-C\%C3\%B3digoPenal-.

- Informe Anteproyecto Código Penal Universidad Adolfo Ibáñez. En línea: https://www.minjusticia.gob.cl/media/2018/12/UAI_Informe_AnteproyectoCodigoPenal2018.pdf.

- Informe Anteproyecto Código Penal Universidad de Chile. En línea: https://www.minjusticia.gob.cl/media/2018/12/UChile_Informe_AnteproyectoCodigoPenal2018.p df.

- Minuta para el análisis del Título XII del Libro Segundo. En línea: https://www.minjusticia.gob.cl/media/2018/10/Cox-Juan-Pablo-Delitos-contra-el-ordenp\%C3\%BAblico.pdf.

- Proyecto de ley Boletín No 10.895-07 "que Modifica diversos cuerpos legales relativos a delitos que afectan a los animales para otorgarles una efectiva protección en materia penal", Cámara de Diputadas y Diputados de Chile, 2016. En línea: https://www.camara.cl/legislacion/ProyectosDeLey/tramitacion.aspx?prmID=11375\&prmBOLETI $\mathrm{N}=10895-07$.

- Proyecto de ley Boletín No 12.822-07 que "Modifica el Código Penal para tipificar como delito la zoofilia", Cámara de Diputadas y Diputados de Chile, 2019. En línea: https://www.camara.cl/legislacion/ProyectosDeLey/tramitacion.aspx?prmID=13370\&prmBOLETI $\mathrm{N}=12822-07$. 